\title{
inorganics
}

ISSN 2304-6740

www.mdpi.com/journal/inorganics

Article

\section{Synthesis of Diazonium Tetrachloroaurate(III) Precursors for Surface Grafting}

Sabine N. Neal ${ }^{1, \dagger}$, Samuel A. Orefuwa ${ }^{1, \dagger}$, Atiya T. Overton, ${ }^{1, \dagger}$, Richard J. Staples ${ }^{2, \dagger}$ and Ahmed A. Mohamed *,1

1 Department of Chemistry, Delaware State University, 1200 N. DuPont Highway, Dover, Delaware 19901, USA; E-Mails: snneal12@students.desu.edu (S.N.N.); sammybid@yahoo.com (S.A.O.); atiya.overton@gmail.com (A.T.O.)

2 Department of Chemistry, Center for Crystallographic Research, Michigan State University, East Lansing, Michigan 48824, USA; E-Mail: staples@chemistry.msu.edu

$\dagger$ These authors contributed equally to this work.

* Author to whom correspondence should be addressed; E-Mail: amohamed@desu.edu; Tel.: +1-302-857-6531; Fax: +1-302-857-6539.

Received: 8 November 2013; in revised form: 4 December 2013 / Accepted: 9 December 2013 / Published: 17 December 2013

Abstract: The synthesis of diazonium tetrachloroaurate(III) complexes $\left[\mathrm{R}-4-\mathrm{C}_{6} \mathrm{H}_{4} \mathrm{~N} \equiv \mathrm{N}\right] \mathrm{AuCl}_{4}$ involves protonation of anilines $\mathrm{CN}-4-\mathrm{C}_{6} \mathrm{H}_{4} \mathrm{NH}_{2}, \mathrm{C}_{8} \mathrm{~F}_{17}-4-\mathrm{C}_{6} \mathrm{H}_{4} \mathrm{NH}_{2}$, and $\mathrm{C}_{6} \mathrm{H}_{13}-4-\mathrm{C}_{6} \mathrm{H}_{4} \mathrm{NH}_{2}$ with tetrachloroauric acid $\mathrm{H}\left[\mathrm{AuCl}_{4}\right] 3 \mathrm{H}_{2} \mathrm{O}$ in acetonitrile followed by one-electron oxidation using $\left[\mathrm{NO} \mathrm{PF}_{6}\right.$. FT-IR shows the diazonium stretching frequency at $2277 \mathrm{~cm}^{-1}(\mathrm{CN}), 2305 \mathrm{~cm}^{-1}\left(\mathrm{C}_{8} \mathrm{~F}_{17}\right)$, and $2253 \mathrm{~cm}^{-1}\left(\mathrm{C}_{6} \mathrm{H}_{13}\right)$. Thermogravimetric Analysis (TGA) shows the high stabilities of the electron-withdrawing substituents $\mathrm{C}_{8} \mathrm{~F}_{17}$ and $\mathrm{CN}$ compared with the electron-donating substituent $\mathrm{C}_{6} \mathrm{H}_{13}$. Residual Gas Analysis (RGA) shows the release of molecular nitrogen as the main gas residue among other small molecular weight chlorinated hydrocarbons and chlorobenzene. Temperature-Dependent X-Ray Powder Diffraction (TD-XRD) shows the thermal decomposition in $\mathrm{C}_{6} \mathrm{H}_{13}$ diffraction patterns at low temperature of $80{ }^{\circ} \mathrm{C}$ which supports the TGA and RGA (TGA-MS) conclusions. X-ray structure shows $\mathrm{N} \equiv \mathrm{N}$ bond distance of approximately $1.10 \AA$ and $\mathrm{N} \equiv \mathrm{N}-\mathrm{C}$ bond angle of $178^{\circ}$.

Keywords: diazonium; tetrachloroaurate(III); X-ray 


\section{Introduction}

Modification of surfaces by redox grafting of diazonium salts is a progressing area of materials chemistry [1-12]. Reduction of aryl diazonium salts has been studied on carbon [3,4,6], semiconductors [6], and nanoparticles surfaces [13-19]. Grafted organic layers demonstrated distinctive performance in the formation of corrosion inhibitor film on iron [10,20], modification of graphene $[2,11,12]$ and diamond [5,21], preparation of diazonium-modified enzyme electrodes [22], immobilization of proteins [5,23], grafting polymers [24], and printing gold via soft lithography [25,26]. In addition to surface modification, aryl diazonium salts have been utilized in palladium-catalyzed cross-coupling reactions. In particular, Heck reactions involving aryl diazonium salts have been widely used in the synthesis of natural products. These electrophiles can also be used in Suzuki-Miyaura, carbonylative, Stille, and carbon-heteroatom cross-couplings [27].

Figure 1. Reductive grafting mechanism of diazonium on surfaces.

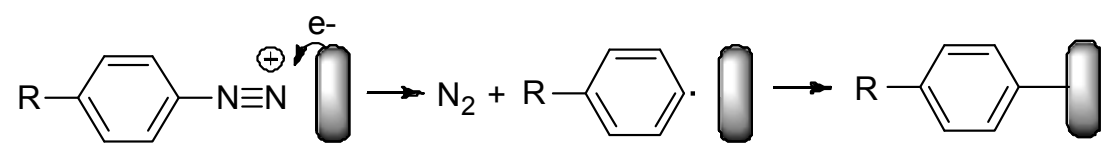

Electrochemical reductive grafting of diazonium has proven to be an effective, versatile, and simple method for producing organic monolayers (Figure 1) [1]. Despite the wide applications of diazonium salts in fundamental and materials chemistry there are many serious drawbacks: their intrinsic instability at room temperature, difficulty to isolate and purify, and their explosive nature [28-30]. In order to avoid some of their limitations diazonium salts must undergo the targeted application in the same medium without isolation. This can be achieved by the in situ diazotization of aryl amines followed by reductive grafting [31].

The electron density model described the bonding in diazonium by synergistic $\mathrm{N} \rightarrow \mathrm{C} \sigma$-bonding and $\mathrm{C} \rightarrow \mathrm{N} \pi$-back-bonding [32-34]. A stabilizing effect for the $\mathrm{C}-\mathrm{N}$ bond includes the formation of charge-transfer complexes, metal-based anion, and coordination [35-37]. Based on the relative size of diazonium and the void of the polyether ring, basicity of the oxygen atoms, and steric hindrance in the ring, it is possible to stabilize the diazonium by complexation with macrocyclic polyethers $[34,35]$. The formation of aryl diazonium ion-crown ether complexes increased the thermal and photochemical stabilities of aryl diazonium ions in solution and in the solid state. Metal-based anion approach was also utilized in order to stabilize the $\mathrm{C}-\mathrm{N}$ bond [36]. A complex of aryl diazonium with the anion $\left[\mathrm{ZnCl}_{4}\right]^{2-}$ was synthesized and $\mathrm{X}$-ray structure was determined [36]. Coordination of the in situ generated diazonium demonstrated to be a plausible route for the stabilization of aliphatic diazonium salts [37].

The synthesis of gold complexes of potential applications in materials chemistry is a rising field of interest [38,39]. We describe a facile procedure for the synthesis of stable diazonium tetrachloroaurate(III) complexes. Preliminary results on the synthesis and grafting have been reported in a communication to Inorganic Chemistry [39]. 


\section{Results and Discussion}

\subsection{Synthesis and Characterization}

In diazotization reactions, a considerably greater amount of $\mathrm{HCl}, \mathrm{H}_{2} \mathrm{SO}_{4}$, or $\mathrm{HClO}_{4}$ acid should be used even if strong basic amines are used as reagents. The tetrachloroauric(III) acid based procedure can be utilized in preparation of a wide range of diazonium compounds in organic solvents without the need for mineral acids (Scheme 1) [39]. Protonation of $\mathrm{CN}-4-\mathrm{C}_{6} \mathrm{H}_{4} \mathrm{NH}_{2}$ with $\mathrm{H}\left[\mathrm{AuCl}_{4}\right] \cdot 3 \mathrm{H}_{2} \mathrm{O}$ in water resulted in the formation of $\mathrm{CN}-4-\mathrm{C}_{6} \mathrm{H}_{4} \mathrm{NH}_{2} \mathrm{AuCl}_{3}, \mathbf{1}$ (Scheme 2). However, the protonation in acetonitrile formed the anilinium tetrachloroaurate(III) complex $\left[\mathrm{CN}-4-\mathrm{C}_{6} \mathrm{H}_{4} \mathrm{NH}_{3}\right] \mathrm{AuCl}_{4}, 2$ (Scheme 3), which was easily oxidized by $[\mathrm{NO}] \mathrm{PF}_{6}$ to form the yellow diazonium tetrachloroaurate(III) complex [CN-4$\left.\mathrm{C}_{6} \mathrm{H}_{4} \mathrm{~N} \equiv \mathrm{N}\right] \mathrm{AuCl}_{4}, 3$, in a high yield. Similarly, the diazonium tetrachloroaurate(III) complexes $\left[\mathrm{C}_{8} \mathrm{~F}_{17^{-}}\right.$ 4- $\left.\mathrm{C}_{6} \mathrm{H}_{4} \mathrm{~N} \equiv \mathrm{N}\right] \mathrm{AuCl}_{4}, 4$, and $\left[\mathrm{C}_{6} \mathrm{H}_{13}-4-\mathrm{C}_{6} \mathrm{H}_{4} \mathrm{~N} \equiv \mathrm{N}\right] \mathrm{AuCl}_{4}$, 5, were synthesized in high yields. The diazonium cation was verified in solution by azo coupling with 2-naphthol to give the dark orange color of diazine. The diazonium tetrachloroaurate(III) complexes are soluble in chloroform, acetonitrile, dimethylformamide, and dimethylsulfoxide. The good solubility is an important advantage over diazonium salts of $\mathrm{BF}_{4}{ }^{-}, \mathrm{Cl}^{-}$, and $\mathrm{PF}_{6}{ }^{-}$. Although caution should be exercised when handling all diazonium salts, there were no indications that gold diazonium compounds are particularly hazardous.

Scheme 1. Synthesis of diazonium tetrachloroaurate(III) complexes.

$$
\begin{aligned}
& \mathrm{R}=\mathrm{CN}, \mathrm{C}_{8} \mathrm{~F}_{17}, \mathrm{C}_{6} \mathrm{H}_{13} \\
& \mathrm{NO}\left[\mathrm{PF}_{6}\right]
\end{aligned}
$$

Scheme 2. Protonation of CN-4- $\mathrm{C}_{6} \mathrm{H}_{4} \mathrm{NH}_{2}$ in water formed aniline gold(III) trichloride, $\mathbf{1}$.

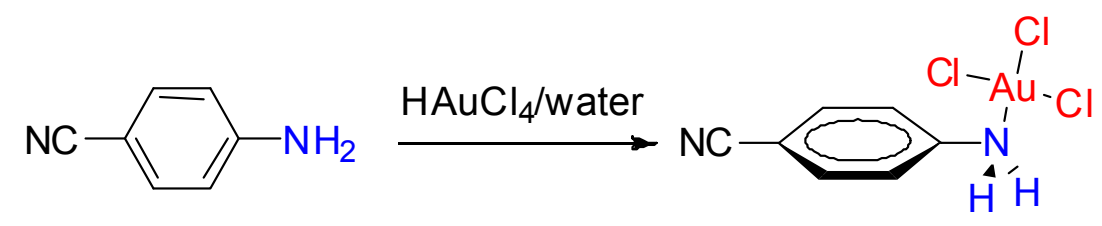

1

Scheme 3. Protonation of $\mathrm{CN}-4-\mathrm{C}_{6} \mathrm{H}_{4} \mathrm{NH}_{2}$ in acetonitrile formed anilinium tetrachloroaurate(III), 2.<smiles>CN(C)c1ccc(N[Hg]C(Cl)(Cl)Cl)cc1</smiles> 
FT-IR spectrum of 3 in the solid state showed the $v_{\mathrm{N} \equiv \mathrm{N}}$ stretching frequency at $2277 \mathrm{~cm}^{-1}$ and ${ }^{1} \mathrm{H}$ NMR spectrum in $\mathrm{CDCl}_{3} / \mathrm{DMSO}-d_{6}$ displayed two doublets assigned to the phenyl protons at $\delta=7.71$ and 8.33 ppm, remarkably shifted from 6.65 and $7.45 \mathrm{ppm}$ in the 4-aminobenzonitrile ligand (Figure 2). FT-IR spectrum of 4 displayed the $v_{\mathrm{N} \equiv \mathrm{N}}$ stretching frequency at $2305 \mathrm{~cm}^{-1}$ and ${ }^{1} \mathrm{H}$ NMR spectrum in $\mathrm{CDCl}_{3} / \mathrm{DMSO}-d_{6}$ displayed the phenyl protons at $\delta=7.67$ and $8.59 \mathrm{ppm}$. FT-IR spectrum of 5 displayed the $v_{\mathrm{N} \equiv \mathrm{N}}$ stretching frequency at $2253 \mathrm{~cm}^{-1}$ and ${ }^{1} \mathrm{H} \mathrm{NMR}$ spectrum in $\mathrm{CDCl}_{3} / \mathrm{DMSO}-d_{6}$ displayed the phenyl protons at $\delta=7.75$ and $8.60 \mathrm{ppm}$.

Figure 2. FT-IR of diazonium tetrachloroaurate(III) complexes $3(\mathrm{CN}), \mathbf{4}\left(\mathrm{C}_{8} \mathrm{~F}_{17}\right)$, and $5\left(\mathrm{C}_{6} \mathrm{H}_{13}\right)$.

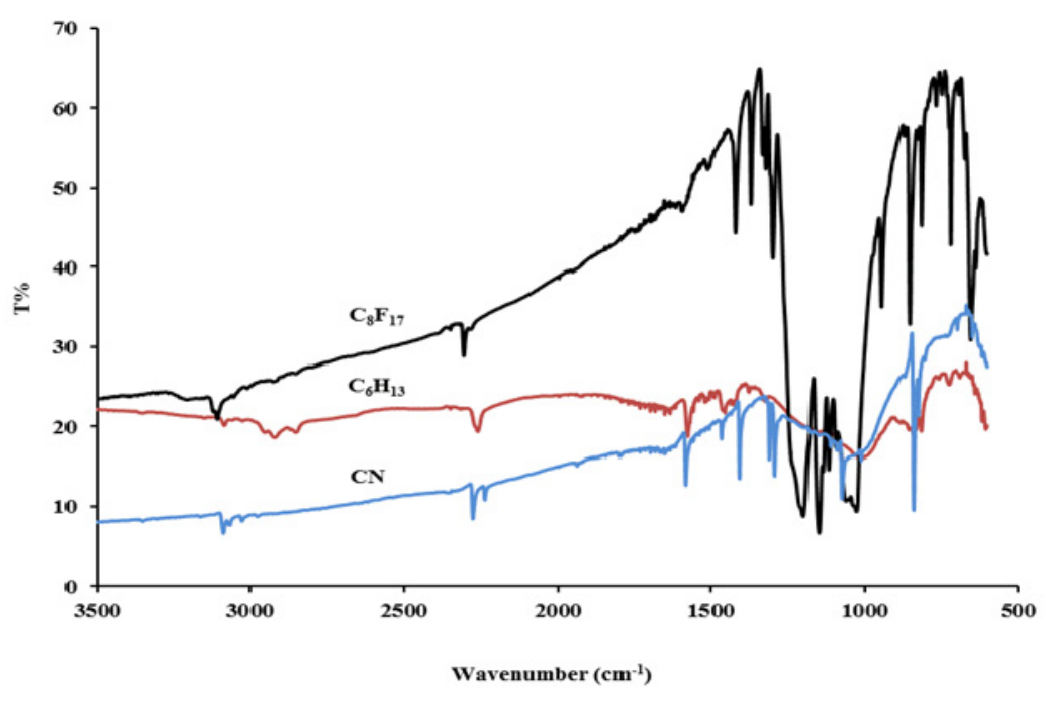

\subsection{X-ray Structure}

From acetonitrile solvent at room temperature well-shaped yellow crystals of diazonium tetrachloroaurate(III) complexes were obtained. Structures 1-3 have been reported in reference [39]. $\mathrm{X}$-ray structure of $\mathbf{5}$ is shown in Figure 3 and X-ray data is presented in Table 1. The crystals are quite stable and no sign of decomposition was seen in the $\mathrm{X}$-ray frames. The $\mathrm{N} \equiv \mathrm{N}$ distance is typical of diazonium, approximately $1.10 \AA$. The unit cell shows the arrangement of the tetrachloroaurate anions around the diazonium. Each diazonium group is surrounded by four $\left[\mathrm{AuCl}_{4}\right]^{-}$normal to the $\mathrm{N} \equiv \mathrm{N}$ axis. The N(outer)...Cl distances are 3.217, 3.267, 3.300, and $3.468 \AA$ (Figure 4). The outer nitrogen is connected to four chloride centers in a square-planar arrangement. The close proximity to the $\mathrm{N} \equiv \mathrm{N}$ group, $\mathrm{Cl} \ldots \mathrm{N} \equiv \mathrm{N}$ interaction, and the fact that the chloride is less nucleophilic in the tetrachloroaurate anion than the free chloride are presumably contributing factors for the increased stability of the diazonium salts.

Several diazonium salts have been isolated in the last few decades and their X-ray structures have been

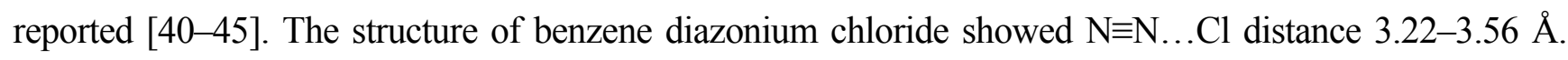
The first example of diazonium stabilization by multiple and close contacts with tosylate anion shows the shortest distances between the diazonium nitrogen and the tosylate oxygen of 2.673-2.770 $\AA$ [46]. shorter than the sum of van der Waals radii $(2.90 \AA)$ [47]. The ionic structures of metal-based diazonium complexes $\left[\mathrm{R}-4-\mathrm{C}_{6} \mathrm{H}_{4} \mathrm{~N} \equiv \mathrm{N}\right] \mathrm{X}\left(\mathrm{X}=\mathrm{SbCl}_{6}, \mathrm{FeCl}_{4}, \mathrm{Cu}_{2} \mathrm{Br}_{2}\right)$ and $\left[\mathrm{R}-4-\mathrm{C}_{6} \mathrm{H}_{4} \mathrm{~N} \equiv \mathrm{N}\right]_{2} \mathrm{ZnCl}_{4}$ show 
the shortest interionic distances between the diazonium and the metal anion occur between the halide and the outer nitrogen than to the ammonium nitrogen [42,43]. Metal-based diazonium complexes structurally characterized so far indicate that the bond order in diazonium nitrogen-nitrogen is close to a triple bond distance of approximately $1.1 \AA$.

Table 1. Crystal data, data collection, and structure refinement for $\left[\mathrm{C}_{6} \mathrm{H}_{13}-4-\right.$ $\left.\mathrm{C}_{6} \mathrm{H}_{4} \mathrm{~N} \equiv \mathrm{N}\right] \mathrm{AuCl}_{4}$.

\begin{tabular}{cc}
\hline Empirical formula & $\mathbf{C}_{\mathbf{1 2}} \mathbf{H}_{\mathbf{1 7}} \mathbf{A u \mathbf { C l }} \mathbf{4} \mathbf{N}_{\mathbf{2}}$ \\
\hline Formula weight & 528.04 \\
Temperature, $\mathrm{K}$ & $173(2)$ \\
Wavelength, $\AA$ & 0.71073 \\
Crystal system & Monoclinic \\
Space group & $\mathrm{P}_{1} / \mathrm{c}$ \\
$\mathrm{a}(\AA) ;\left(^{\circ}\right)$ & $15.5144(3)$ \\
$\mathrm{b}(\AA) ;\left(^{\circ}\right)$ & $38.4270(8)$ \\
$\mathrm{c}(\AA) ;\left(^{\circ}\right)$ & $90.0250(10)$ \\
Volume, $\AA^{3}$ & $8.7773(2)$ \\
$\mathrm{Z}$ & $5232.78(19)$ \\
Density $($ cal. $), \mathrm{Mg} / \mathrm{m}^{3}$ & 12 \\
Abs. coefficient, $\mathrm{mm}{ }^{-1}$ & 2.011 \\
GOF on $F^{2}$ & 21.395 \\
R1, wR2 $[I>2 \sigma(\mathrm{I})]$ & $0.0568,0.1530$ \\
\hline
\end{tabular}

Figure 3. Structure of $\left[\mathrm{C}_{6} \mathrm{H}_{13}-4-\mathrm{C}_{6} \mathrm{H}_{4} \mathrm{~N} \equiv \mathrm{N}\right] \mathrm{AuCl}_{4}$, 5, at $30 \%$ probability. Bond distances $(\AA): \mathrm{N}(1 \mathrm{~A})-\mathrm{N}(2 \mathrm{~A}) 1.086(11)$ and $\mathrm{N}(2)-\mathrm{C}(1) 1.400(12)$. Bond angles $\left({ }^{\circ}\right): \mathrm{N}(1 \mathrm{~A})-\mathrm{N}(2 \mathrm{~A})-$ $\mathrm{C}(1 \mathrm{~A})$ 178.7(9).

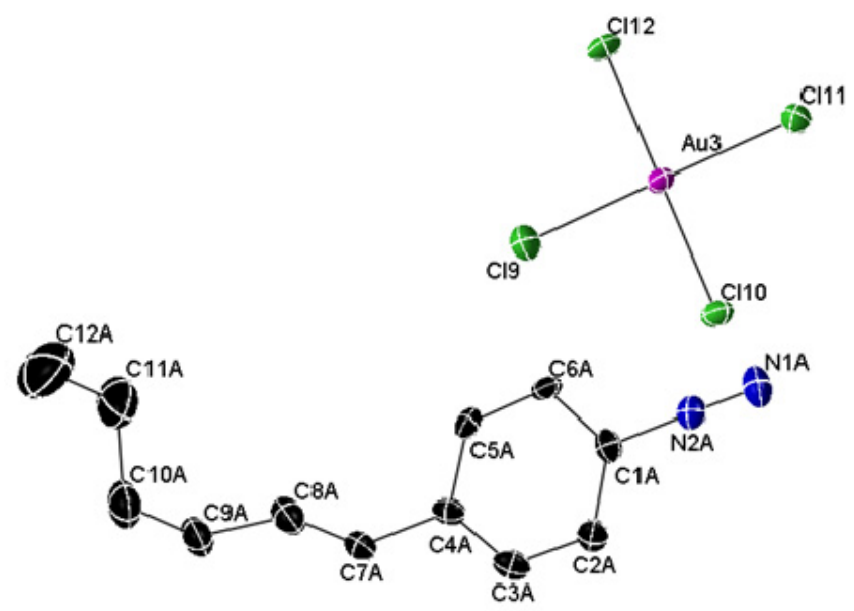


Figure 4. Unit cell of $\left[\mathrm{C}_{6} \mathrm{H}_{13}-4-\mathrm{C}_{6} \mathrm{H}_{4} \mathrm{~N} \equiv \mathrm{N}\right] \mathrm{AuCl}_{4}$.

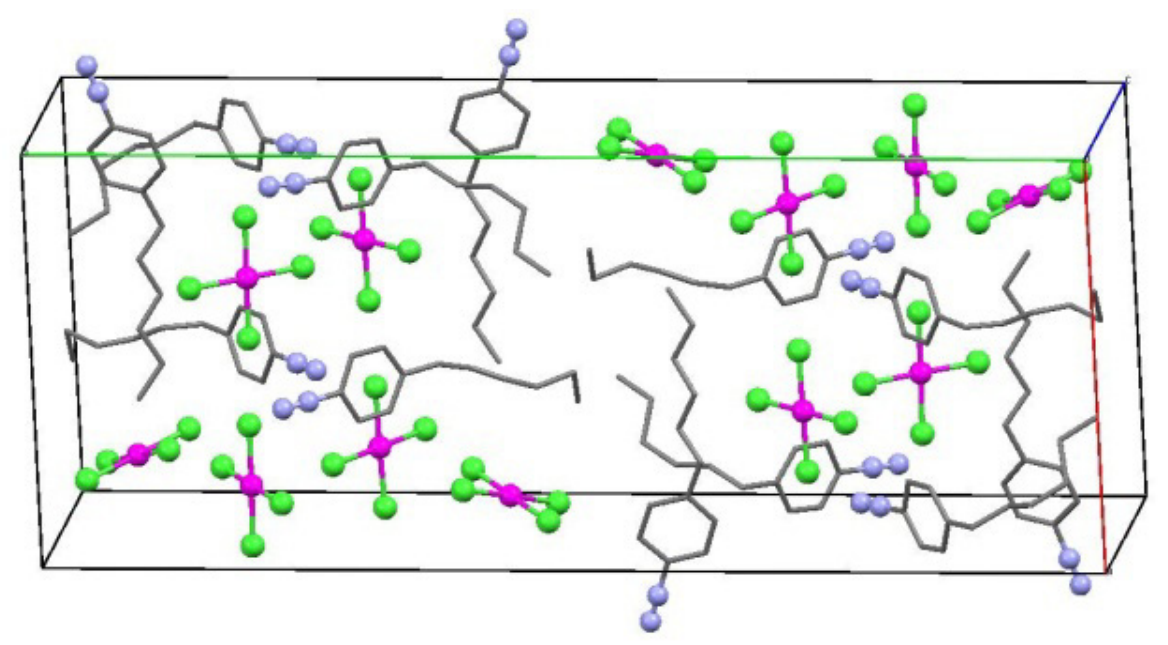

\subsection{Thermal Stability and Residual Gas Analysis Studies}

The enormous literature on the thermal stability of diazonium salts covers the greatest variety with inorganic stabilizing anions. Study clearly indicates an important influence of the stabilizing anion, substituent, and water in the unit cell. A correlation between the rate of diazonium nitrogen evolution and the electronic configuration and the electronegativity of the metal ion has been studied [48]. It cannot be concluded from the correlation study if the type of metal has a direct effect on diazonium stability due to the failure to stabilize diazonium salts with some of the metal chlorides used.

When examined by Thermal Gravimetric Analysis (TGA) at a heating rate of $2.0{ }^{\circ} \mathrm{C} / \mathrm{min}$ the diazonium tetrachloroaurate(III) complexes started the decomposition at approximately $100{ }^{\circ} \mathrm{C}$. The TGA curve of 4 displays the loss of nitrogen and chloride in the first stage of $10 \%$ which ends at about $100{ }^{\circ} \mathrm{C}$ followed by a more abrupt weight loss until $150{ }^{\circ} \mathrm{C}$. From $150{ }^{\circ} \mathrm{C}$ to $400{ }^{\circ} \mathrm{C}$ the sample losses ca. $40 \%$ weight (Figure 5). The poor volatility of the fluorinated ligand conceivably is the reason for the sluggish weight loss. The percentage gold residue from 5 is 23\% (theoretical 23\%). TGA of 3 displays a $40 \%$ gold residue (theoretical $42 \%$ ) and $40 \%$ (theoretical 37\%) for 5 .

Temperature-Dependent X-Ray Powder Diffraction (TD-XRD) patterns at 25, 50, 100, and $150{ }^{\circ} \mathrm{C}$ display peaks associated with the decomposition of 4 , however, the peaks associated with the elemental gold formation are absent within the same temperature range (Figure 6). The diazonium tetrachloroaurate(III) peaks disappeared after heating above $150{ }^{\circ} \mathrm{C}$ with the concomitant appearance of a new set of peaks. The cubic gold reflections became more intense within the $250-300{ }^{\circ} \mathrm{C}$ range. The TD-XRD associated peaks of 5 (Figure 7) show elemental gold at lower temperature than 4. The diffraction patters also confirmed the highly crystalline nature of gold residues after complete decomposition of 4 and 5. Bragg reflections at $2 \theta 38.1^{\circ}, 44.5^{\circ}, 64.8^{\circ}$, and $78.8^{\circ}$ could be indexed based on the face-centered cubic gold structure.

The gases released from diazonium tetrachloroaurate(III) pyrolysis were identified by Residual Gas Analysis (RGA) studies. Figure 8 shows the partial pressure of nitrogen for $\mathbf{4}$ and $\mathbf{5}$. In addition to nitrogen, the gases released from each complex in the temperature range $100-450{ }^{\circ} \mathrm{C}$ include chlorobenzene, chlorinated small molecular weight hydrocarbons, and chlorine. The fluorous chain and phenyl groups can be clearly seen leaving as $\mathrm{PhCl}, \mathrm{PhF}$, and low molecular weight halogenated 
hydrocarbon fractions $\mathrm{CH}_{2} \mathrm{Cl}_{2}, \mathrm{CCl}_{4}, \mathrm{CHCl}_{3}, \mathrm{C}_{2} \mathrm{HCl}_{3}, \mathrm{CH}_{3} \mathrm{~F}$, and $\mathrm{CF}_{4}$ (Table 2). In pyrolysis gas chromatography, the major gases of $\left[\mathrm{R}_{2} \mathrm{~N}-4-\mathrm{C}_{6} \mathrm{H}_{4} \mathrm{~N} \equiv \mathrm{N}\right]_{2} \mathrm{ZnCl}_{4}$ decomposition between $160{ }^{\circ} \mathrm{C}$ and $250{ }^{\circ} \mathrm{C}$ were, in addition to nitrogen, the corresponding chloroaromatics due to the replacement of diazonium by chlorine [49].

Table 2. Partial pressure of gases (Torr) released from Residual Gas Analysis (RGA) decomposition of $\left[\mathrm{C}_{8} \mathrm{~F}_{17}-4-\mathrm{C}_{6} \mathrm{H}_{4} \mathrm{~N} \equiv \mathrm{N}\right] \mathrm{AuCl}_{4}$ at $450{ }^{\circ} \mathrm{C}$.

\begin{tabular}{cccc}
\hline Gas & Partial pressure & Gas & Partial pressure \\
\hline $\mathrm{N}_{2}$ & $2.60 \times 10^{-7}$ & $\mathrm{Cl}_{2}$ & $1.08 \times 10^{-11}$ \\
$\mathrm{CH}_{3} \mathrm{~F}$ & $9.10 \times 10^{-1 \circ}$ & $\mathrm{C}_{6} \mathrm{H}_{5} \mathrm{Cl}$ & $6.47 \times 10^{-12}$ \\
$\mathrm{CH}_{2} \mathrm{Cl}_{2}$ & $5.47 \times 10^{-1 \circ}$ & $\mathrm{C}_{6} \mathrm{H}_{5} \mathrm{~F}$ & $5.21 \times 10^{-12}$ \\
$\mathrm{CHCl}_{3}$ & $2.90 \times 10^{-11}$ & $\mathrm{CCl}_{4}$ & $4.29 \times 10^{-12}$ \\
$\mathrm{CF}_{4}$ & $1.10 \times 10^{-11}$ & & \\
\hline
\end{tabular}

Decomposition of the diazonium tetrachloroaurate(III) complexes, ready evolution of nitrogen, under their respective temperatures using melting point apparatus occurred without melting. It appears that for diazonium tetrachloroaurate(III) complexes there are small temperature ranges over which the gases are evolved. When a heat source was applied to $\mathbf{3}$ the crystals seemed to release gases beginning at about $129{ }^{\circ} \mathrm{C}$ and continued until about $134{ }^{\circ} \mathrm{C}$. When a heat source was applied to 5 the gases were released at temperature range of $110-114^{\circ} \mathrm{C}$ and in 4 the gases were released at lower range of $96-97^{\circ} \mathrm{C}$.

Figure 5. TGA of $\left[\mathrm{CN}-4-\mathrm{C}_{6} \mathrm{H}_{4} \mathrm{~N} \equiv \mathrm{N}\right] \mathrm{AuCl}_{4}, \quad\left[\mathrm{C}_{8} \mathrm{~F}_{17}-4-\mathrm{C}_{6} \mathrm{H}_{4} \mathrm{~N} \equiv \mathrm{N}\right] \mathrm{AuCl}_{4}$, and $\left[\mathrm{C}_{6} \mathrm{H}_{13}-4-\mathrm{C}_{6} \mathrm{H}_{4} \mathrm{~N} \equiv \mathrm{N}\right] \mathrm{AuCl}_{4}$.

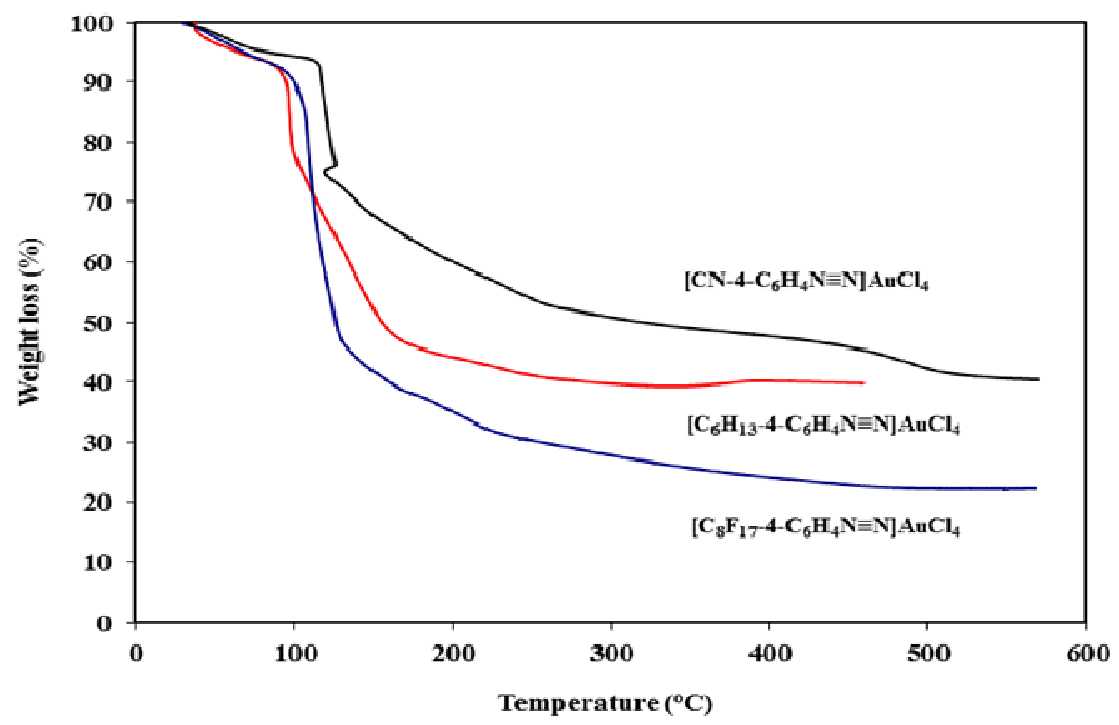


Figure 6. Temperature-Dependent $\mathrm{X}$-ray Powder Diffraction patterns of $\left[\mathrm{C}_{8} \mathrm{~F}_{17}-4-\right.$ $\left.\mathrm{C}_{6} \mathrm{H}_{4} \mathrm{~N} \equiv \mathrm{N}\right] \mathrm{AuCl}_{4}$.

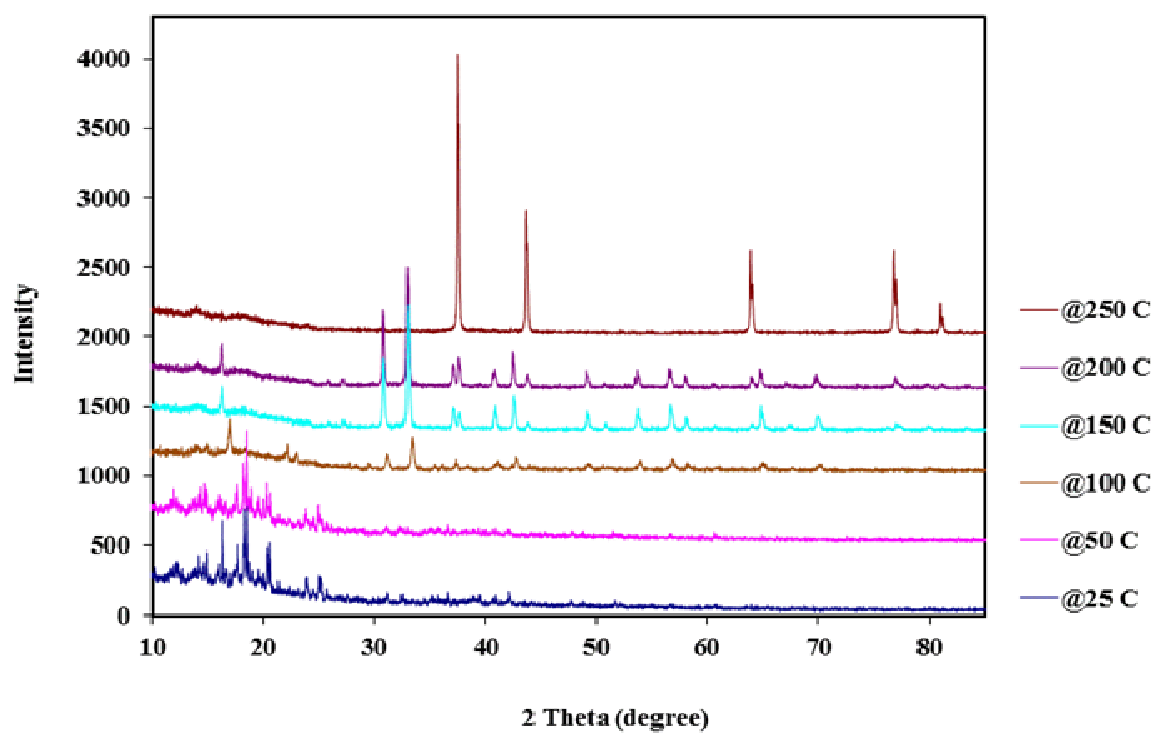

Figure 7. Temperature-Dependent $\mathrm{X}$-ray Powder Diffraction patterns of $\left[\mathrm{C}_{6} \mathrm{H}_{13}-4\right.$ $\left.\mathrm{C}_{6} \mathrm{H}_{4} \mathrm{~N} \equiv \mathrm{N}\right] \mathrm{AuCl}_{4}$.

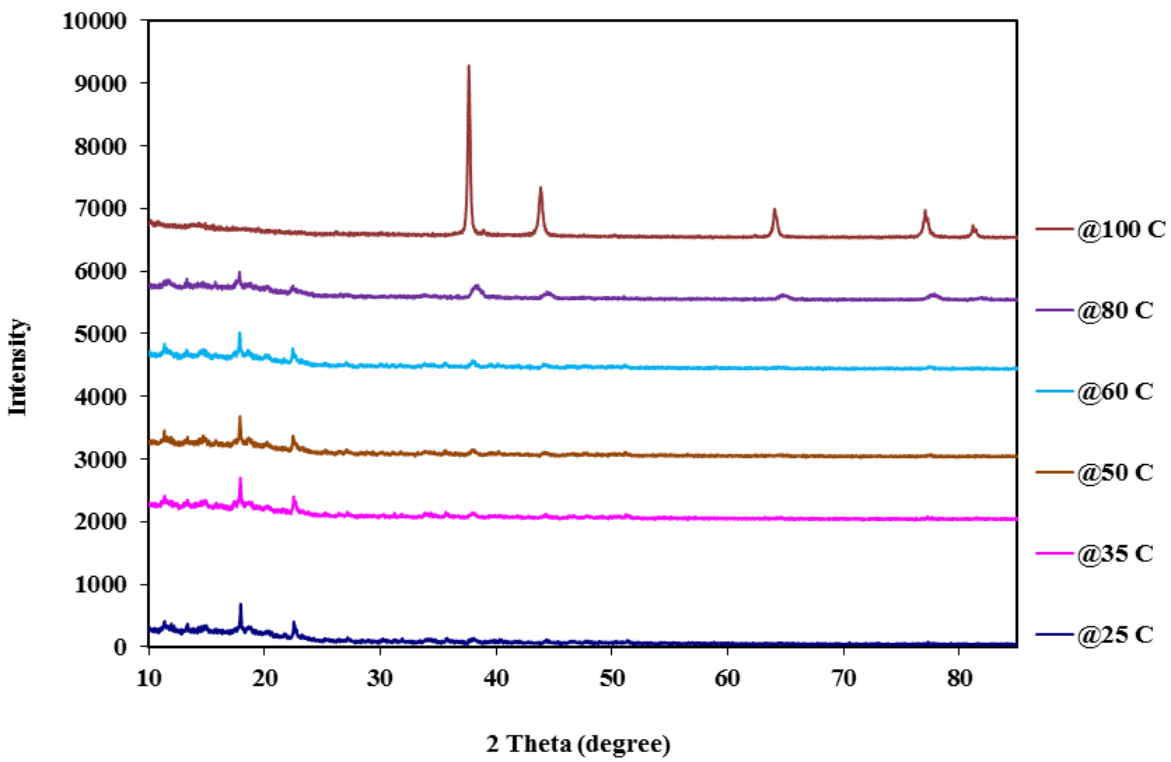


Figure 8. Residual Gas Analysis (RGA) of $\left[\mathrm{C}_{8} \mathrm{~F}_{17}-4-\mathrm{C}_{6} \mathrm{H}_{4} \mathrm{~N} \equiv \mathrm{N}\right] \mathrm{AuCl}_{4}$ and $\left[\mathrm{C}_{6} \mathrm{H}_{13}-4-\right.$ $\left.\mathrm{C}_{6} \mathrm{H}_{4} \mathrm{~N} \equiv \mathrm{N}\right] \mathrm{AuCl}_{4}$.

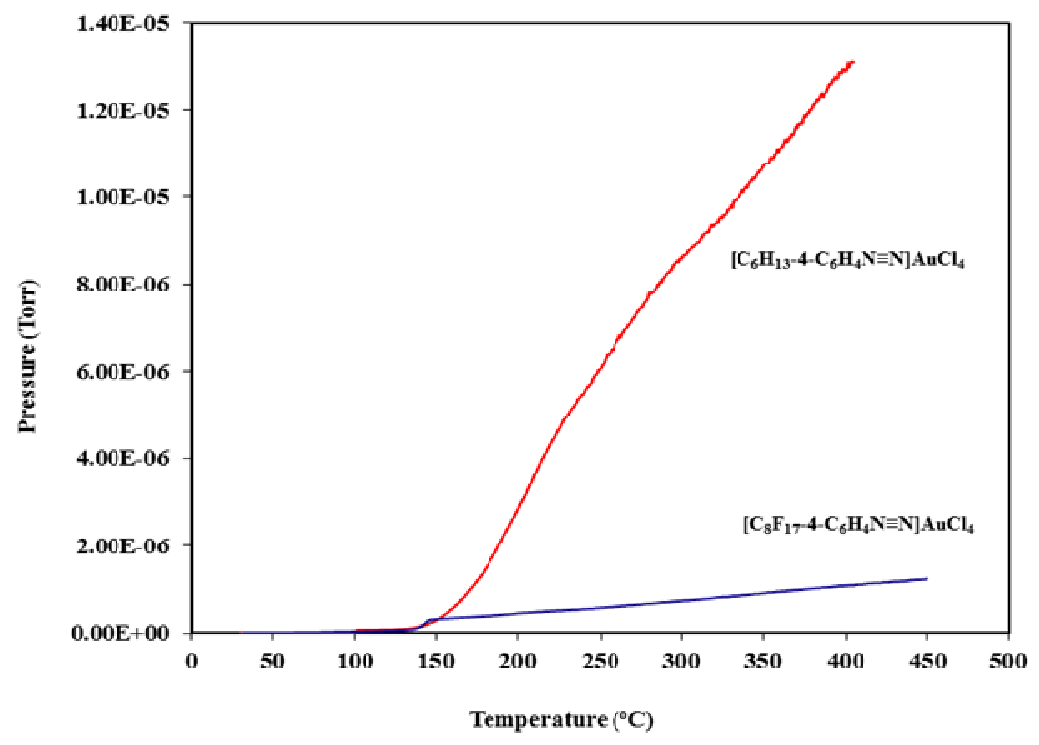

\section{Experimental Section}

\subsection{General Procedures}

Unless stated otherwise, all manipulations were carried out in either a $\mathrm{N}_{2}$-filled Vacuum Atmospheres Co. glove box or on a Schlenk line using $\mathrm{N}_{2}$. Toluene, acetonitrile, $\mathrm{CN}-4-\mathrm{C}_{6} \mathrm{H}_{4} \mathrm{NH}_{2}$, $\mathrm{C}_{8} \mathrm{~F}_{17}-4-\mathrm{C}_{6} \mathrm{H}_{4} \mathrm{NH}_{2}, \mathrm{C}_{6} \mathrm{H}_{13}-4-\mathrm{C}_{6} \mathrm{H}_{4} \mathrm{NH}_{2}, \mathrm{CDCl}_{3}, \quad \mathrm{DMSO}-d_{6}, \quad[\mathrm{NO}] \mathrm{PF}_{6}$, and $\mathrm{H}\left[\mathrm{AuCl}_{4}\right] 3 \mathrm{H}_{2} \mathrm{O}$ were purchased from Sigma-Aldrich. All other commercially available reagents were used as received.

\subsection{Physical Measurements}

Infrared spectra were recorded in the $4000-400 \mathrm{~cm}^{-1}$ range using a Perkin-Elmer FT-IR Spectrum 1000 spectrophotometer. C, H, and N analyses were carried out by Columbia Analytical Services, Tucson, Arizona. ${ }^{1} \mathrm{H}$ and ${ }^{13} \mathrm{C}$ NMR spectra were recorded on a JEOL $400 \mathrm{MHz}$. Chemical shifts are reported relative to the chloroform solvent peak.

\subsection{Thermogravimetric Analysis and Residual Gas Analysis}

Thermal stability was studied using a Perkin-Elmer TG/DTA Thermogravimetric analyzer. The scan rate was set at a $2{ }^{\circ} \mathrm{C} / \mathrm{min}$ from room temperature to $500{ }^{\circ} \mathrm{C}$. The TGA analysis was carried out in air and in argon atmosphere. Residual gas analyses were carried out using RGA Pro 2000 from Stanford Research Systems. Non-ambient (Temperature Program) X-ray diffraction analysis was carried out on a Panalytical X'Pert Pro X-ray Diffractometer (Model PW3040 Pro) using copper $\mathrm{K}$-alpha radiation $(\lambda=0.154178 \mathrm{~nm})$. The instrument was operated at $40 \mathrm{KV}$ and $20 \mathrm{~mA}$ on an HTK 1200 oven stage. 


\subsection{X-ray Diffraction}

Data for complexes CN-4- $\mathrm{C}_{6} \mathrm{H}_{4} \mathrm{NH}_{2} \mathrm{AuCl}_{3}, \mathbf{1}$, [CN-4- $\left.\mathrm{C}_{6} \mathrm{H}_{4} \mathrm{NH}_{3}\right] \mathrm{AuCl}_{4}$, 2, and $\left[\mathrm{CN}-4-\mathrm{C}_{6} \mathrm{H}_{4} \mathrm{~N} \equiv \mathrm{N}\right] \mathrm{AuCl}$, 3, were collected using a Bruker D8 tricycles diffractometer with APEX II detector CCD based equipped with an LT-2 low-temperature apparatus operating at $110 \mathrm{~K}$. Data for 5 was collected at $213 \mathrm{~K}$ with a Siemens SMART CCD diffractometer equipped with an LT-2 low-temperature apparatus. A suitable crystal was chosen and mounted on a glass fiber using grease. Cell parameters were determined and refined using APEX II software on all observed reflections which corrects for Lp and decay [50,51]. Absorption corrections were applied using SADABS supplied by George Sheldrick [52]. The structures are solved by the direct method using the SHELXS-97 program and refined by least squares method on $\mathrm{F}^{2}$, SHELXL-97, incorporated in SHELXTL-PC V $5.03[53,54]$.

\subsection{Syntheses}

Synthesis of CN-4- $\mathbf{C}_{6} \mathbf{H}_{4} \mathbf{N H}_{2} \mathbf{A u C l}_{3}$, 1: To a $67 \mathrm{mg}(0.5 \mathrm{mmol})$ of $\mathrm{CN}-4-\mathrm{C}_{6} \mathrm{H}_{4} \mathrm{NH}_{2}$ suspended in 15 of $\mathrm{mL}$ distilled water was added $190 \mathrm{mg}(0.5 \mathrm{mmol}) \mathrm{H}\left[\mathrm{AuCl}_{4}\right] 3 \mathrm{H}_{2} \mathrm{O}$ at room temperature. The water insoluble yellow complex was stirred for $2 \mathrm{~h}$. The yellow precipitate was filtered, washed twice with $5 \mathrm{~mL}$ of water, and dried under vacuum to give $153 \mathrm{mg}$. Yield 64.01\%. ${ }^{1} \mathrm{H}$ NMR $\left(\mathrm{CDCl}_{3} / \mathrm{DMSO}-d_{6}\right): \delta 7.20(\mathrm{~d}$, $9.7 \mathrm{~Hz}, 2 \mathrm{H}), 7.58(\mathrm{~d}, 9.7 \mathrm{~Hz}, 2 \mathrm{H}) .{ }^{13} \mathrm{C} \mathrm{NMR}\left(\mathrm{CDCl}_{3} / \mathrm{DMSO}-d_{6}\right): \delta 119.62(\mathrm{C}-1), 125.0(\mathrm{C}-2, \mathrm{C}-3)$, $133.63(\mathrm{C}-4), 143.0(\mathrm{CN})$. Elemental analysis calculated for $\mathrm{C}_{7} \mathrm{H}_{6} \mathrm{AuCl}_{3} \mathrm{~N}_{2}: \% \mathrm{C}=19.95, \% \mathrm{H}=1.43$, $\% \mathrm{~N}=6.65$. Exp: $\% \mathrm{C}=19.89, \% \mathrm{H}=1.40, \% \mathrm{~N}=6.75$.

Synthesis of $\left[\mathbf{C N}-4-\mathbf{C}_{6} \mathbf{H}_{4} \mathbf{N H}_{3}\right] \mathbf{A u C l} \mathbf{u}_{4}$, 2: To a $67 \mathrm{mg}(0.5 \mathrm{mmol})$ of CN-4-C 6 - $\mathrm{H}_{4} \mathrm{NH}_{2}$ dissolved in $10 \mathrm{~mL}$ of $\mathrm{CH}_{3} \mathrm{CN}$ was added $197 \mathrm{mg}(0.5 \mathrm{mmol}) \mathrm{H}\left[\mathrm{AuCl}_{4}\right] 3 \mathrm{H}_{2} \mathrm{O}$ at room temperature. The yellow solution was stirred for $2 \mathrm{~h}$ and $30 \mathrm{~mL}$ of cold ether was added. The reaction mixture was stirred for additional $2 \mathrm{~h}$ and the precipitate was filtered, washed twice with $5 \mathrm{~mL}$ cold ether, and dried under vacuum to give $228 \mathrm{mg}$. Yield 87.69\%. ${ }^{1} \mathrm{H}$ NMR $\left(\mathrm{CDCl}_{3} / \mathrm{DMSO}_{-} \mathrm{d}_{6}\right): \delta 6.70(\mathrm{~d}, 9.3 \mathrm{~Hz}, 2 \mathrm{H}), 7.17(\mathrm{~d}, 9.3 \mathrm{~Hz}, 2 \mathrm{H})$. ${ }^{13} \mathrm{C} \mathrm{NMR}\left(\mathrm{CDCl}_{3} / \mathrm{DMSO}_{-}\right.$): $\delta 104.5$ (C-1), 118.9 (C-2), 133.39 (C-3, C-4), 144.24 (CN). Elemental analysis calculated for $\mathrm{C}_{7} \mathrm{H}_{7} \mathrm{AuCl}_{4} \mathrm{~N}_{2}: \% \mathrm{C}=18.36, \% \mathrm{H}=1.54, \% \mathrm{~N}=6.12$. Exp: $\% \mathrm{C}=18.28, \% \mathrm{H}=$ $1.56, \% \mathrm{~N}=6.09$.

Synthesis of $\left[\mathbf{C N}-4-\mathbf{C}_{6} \mathbf{H}_{4} \mathbf{N} \equiv \mathbf{N}\right] \mathbf{A u C l} \mathbf{u}_{4}, 3$ : To a $118 \mathrm{mg}(1.0 \mathrm{mmol})$ of $\mathrm{CN}-4-\mathrm{C}_{6} \mathrm{H}_{4} \mathrm{NH}_{2}$ dissolved in $10 \mathrm{~mL}$ of $\mathrm{CH}_{3} \mathrm{CN}$ was added $391 \mathrm{mg}(1.0 \mathrm{mmol}) \mathrm{H}\left[\mathrm{AuCl}_{4}\right] 3 \mathrm{H}_{2} \mathrm{O}$ at $0{ }^{\circ} \mathrm{C}$. A $184 \mathrm{mg}(1.0 \mathrm{mmol})$ [NO]PF 6 was added and stirring continued at $0{ }^{\circ} \mathrm{C}$. The yellow solution was stirred for $2 \mathrm{~h}$ and $30 \mathrm{~mL}$ of cold ether was added. The reaction mixture was stirred for additional $2 \mathrm{~h}$ and the precipitate was filtered, washed twice with $5 \mathrm{~mL}$ of cold ether, and dried under vacuum to give $420 \mathrm{mg}$. Yield $91.90 \%$. ${ }^{1} \mathrm{H} \mathrm{NMR}\left(\mathrm{CDCl}_{3} / \mathrm{DMSO}-\right.$ $\left.d_{6}\right): \delta 7.71(\mathrm{~d}, 9.7 \mathrm{~Hz}, 2 \mathrm{H}), 8.33(\mathrm{~d}, 9.7 \mathrm{~Hz}, 2 \mathrm{H}) .{ }^{13} \mathrm{C} \mathrm{NMR}\left(\mathrm{CDCl}_{3} / \mathrm{DMSO}-\mathrm{d}_{6}\right): \delta 115.4(\mathrm{C} 1), 120.3(\mathrm{C} 2)$, 122.4 (C3), 133.3.24 (C4), $134.3(\mathrm{CN})$. Elemental analysis calculated for $\mathrm{C}_{7} \mathrm{H}_{4} \mathrm{AuCl}_{4} \mathrm{~N}_{3}: \% \mathrm{C}=17.93, \% \mathrm{H}$ $=0.86, \% \mathrm{~N}=8.96$. Exp: $\% \mathrm{C}=17.95, \% \mathrm{H}=0.79, \% \mathrm{~N}=8.84$. FT-IR (solid): $v_{\mathrm{N} \equiv \mathrm{N}}$ stretching frequency at $2277 \mathrm{~cm}^{-1}$. UV-Vis $\left(2.13 \times 10^{-4} \mathrm{M}\right.$ in $\left.\mathrm{CH}_{3} \mathrm{CN}\right): 318 \mathrm{~nm}\left(10,938 \mathrm{M}^{-1} \mathrm{~cm}^{-1}\right)$.

Synthesis of $\left[\mathbf{C}_{\mathbf{8}} \mathbf{F}_{\mathbf{1 7}}-\mathbf{4}-\mathbf{C}_{\mathbf{6}} \mathbf{H}_{\mathbf{4}} \mathbf{N} \equiv \mathbf{N}\right] \mathbf{A u C l}_{\mathbf{4}}$, 4: To a $512 \mathrm{mg}(1.0 \mathrm{mmol})$ of $\mathrm{C}_{8} \mathrm{~F}_{17}-4-\mathrm{C}_{6} \mathrm{H}_{4} \mathrm{NH}_{2}$ dissolved in $20 \mathrm{~mL}$ of toluene at $0{ }^{\circ} \mathrm{C}$ was added $400 \mathrm{mg}(1.0 \mathrm{mmol}) \mathrm{H}\left[\mathrm{AuCl}_{4}\right] 3 \mathrm{H}_{2} \mathrm{O}$ dissolved in $3 \mathrm{~mL}$ of acetonitrile. The solution was stirred for $2 \mathrm{~h}$ before a $173 \mathrm{mg}(1.0 \mathrm{mmol})$ [NO]PF 6 dissolved in $3 \mathrm{~mL}$ 
of acetonitrile was added. The dark red solution was stirred for an additional $2 \mathrm{~h}$ at $0{ }^{\circ} \mathrm{C}$ under nitrogen during which canary yellow microcrystals precipitated. The microcrystals were filtered, washed twice with $5 \mathrm{~mL}$ of cold toluene, and dried under vacuum to give $835 \mathrm{mg}$. Yield $96.70 \%$. ${ }^{1} \mathrm{H}$ NMR

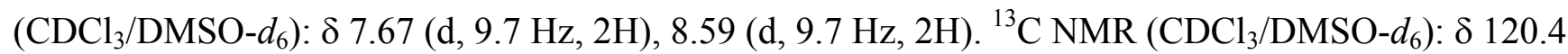
(C-1), 129.5 (C-2), 133.6 (C-3), 138.0 (C-4). Elemental analysis calculated for $\mathrm{C}_{14} \mathrm{~F}_{17} \mathrm{H}_{4} \mathrm{AuCl}_{4} \mathrm{~N}_{2}$ : $\% \mathrm{C}=19.51, \% \mathrm{H}=0.47, \% \mathrm{~N}=3.25$. Exp: $\% \mathrm{C}=19.33, \% \mathrm{H}=0.66, \% \mathrm{~N}=3.11$. FT-IR (solid): $v_{\mathrm{N} \equiv \mathrm{N}}$ stretching frequency at $2305 \mathrm{~cm}^{-1}$. UV-Vis $\left(1.89 \times 10^{-4} \mathrm{M}\right.$ in $\left.\mathrm{CH}_{3} \mathrm{CN}\right): 305 \mathrm{~nm}\left(2983 \mathrm{M}^{-1} \mathrm{~cm}^{-1}\right)$.

Synthesis of $\left[\mathbf{C}_{6} \mathbf{H}_{13}-\mathbf{4}-\mathbf{C}_{6} \mathbf{H}_{\mathbf{4}} \mathbf{N} \equiv \mathbf{N}\right] \mathbf{A u C l} \mathbf{A l}_{4}, \mathbf{5 :}$ To a $178 \mathrm{mg}(1.0 \mathrm{mmol})$ of $\mathrm{C}_{6} \mathrm{H}_{13}-4-\mathrm{C}_{6} \mathrm{H}_{4} \mathrm{NH}_{2}$ dissolved in $20 \mathrm{~mL}$ of toluene at $0{ }^{\circ} \mathrm{C}$ was added $400 \mathrm{mg}(1.0 \mathrm{mmol}) \mathrm{H}\left[\mathrm{AuCl}_{4}\right] 3 \mathrm{H}_{2} \mathrm{O}$ dissolved in $3 \mathrm{~mL}$ of acetonitrile. The solution was stirred for $2 \mathrm{~h}$ before a $173 \mathrm{mg}(1.0 \mathrm{mmol})[\mathrm{NO}] \mathrm{PF}_{6}$ dissolved in $3 \mathrm{~mL}$ of acetonitrile was added. The solution was stirred for an additional $2 \mathrm{~h}$ at $0{ }^{\circ} \mathrm{C}$ under nitrogen and was kept in the fridge overnight to form yellow microcrystals out of olive green solution. The precipitate was filtered, washed twice with $5 \mathrm{~mL}$ of cold toluene, and dried under vacuum to give $425 \mathrm{mg}$. Yield 80.49\%. ${ }^{1} \mathrm{H} \mathrm{NMR}\left(\mathrm{CDCl}_{3} / \mathrm{DMSO}-d_{6}\right): \delta 7.75(\mathrm{~d}, 8.1 \mathrm{~Hz}, 2 \mathrm{H}), 8.60(\mathrm{~d}, 8.1 \mathrm{~Hz}, \mathrm{H})$. Elemental analysis calculated for $\mathrm{C}_{12} \mathrm{H}_{17} \mathrm{AuCl}_{4} \mathrm{~N}_{2}: \% \mathrm{C}=27.31, \% \mathrm{H}=3.14, \% \mathrm{~N}=5.25$. Exp: $\% \mathrm{C}=27.29, \% \mathrm{H}=3.24$, $\% \mathrm{~N}=5.31$. FT-IR (solid): $v_{\mathrm{N} \equiv \mathrm{N}}$ stretching frequency at $2253 \mathrm{~cm}^{-1}$. UV-Vis $\left(5.8 \times 10^{-4}\right.$ in $\left.\mathrm{CH}_{3} \mathrm{CN}\right)$ : $279 \mathrm{~nm}\left(14,884 \mathrm{M}^{-1} \mathrm{~cm}^{-1}\right)$.

\section{Conclusions}

We described the synthesis of stable diazonium tetrachloroaurate(III) complexes of potential applications in surface grafting. The structures are similar to inorganic based anions diazonium salts. The synthesized compounds are soluble in several organic solvents and stable at room temperature in the solid state and solution. Research continues on the diazonium tetrachloroaurate(III) complexes to synthesize robust gold-carbon nanoparticles and films.

\section{Acknowledgments}

Andrew Goudy of Delaware State University is acknowledged for the TGA, RGA, and TD-XRD measurements.

\section{Conflicts of Interest}

The authors declare no conflict of interest.

\section{References}

1. Chehimi, M.M. Aryl Diazonium Salts: New Coupling Agents in Polymer and Surface Science; Wiley-VCH: Weinheim, Germany, 2012.

2. Sun, Z.; James, D.K.; Tour, J.M. Graphene Chemistry: Synthesis and Manipulation. J. Phys. Chem. Lett. 2011, 2, 2425-2432.

3. Breton, T.; Bélanger, D. Modification of Carbon Electrode with Aryl Groups having an Aliphatic Amine by Electrochemical Reduction of in situ Generated Diazonium Cations. Langmuir 2008, 24, 8711-8718. 
4. Allongue, P.; Delamar, M.; Desbat, B.; Fagebaume, O.; Hitmi, R.; Pinson, J.; Saveant, J.M. Covalent Modification of Carbon Surfaces by Aryl Radicals Generated from the Electrochemical Reduction of Diazonium Salts. J. Am. Chem. Soc. 1997, 119, 201-207.

5. Salmi, Z.; Lamouri, A.; Decorse, P.; Jouini, M.; Boussadi, A.; Achard, J.; Gicquel, A.; MahoucheChergui, S.; Carbonnier, B.; Chehimi, M.M. Grafting Polymer-Protein Bioconjugate to BoronDoped Diamond using Aryl Diazonium Coupling Agents. Diamond Rel. Mater. 2013, 40, 60-80.

6. Lehr, J.; Garrett, D.J.; Paulik, M.G.; Flavel, B.S.; Brooksby, P.A.; Williamson, B.E.; Downard, A.J. Patterning of Metal, Carbon, and Semiconductor Substrates with Thin Organic Films by Microcontact Printing with Aryldiazonium Salt Inks. Anal. Chem. 2010, 82, 7027-7070.

7. Aswal, D.K.; Koiry, S.P.; Jousselme, B.; Gupta, S.K.; Palacin, S.; Yakhmi, J.V. Hybrid Moleculeon-Silicon Nanoelectronics: Electrochemical Processes for Grafting and Printing of Monolayers. Physica E 2009, 41, 325-344.

8. Gooding, J.J.; Ciampi, S. The Molecular Level Modification of Surfaces: From Self-Assembled Monolayers to Complex Molecular Assemblies. Chem. Soc. Rev. 2011, 40, 2704-2718.

9. Bélanger, D.; Pinson, J. Electrografting: A Powerful Method for Surface Modification. Chem. Soc. Rev. 2011, 40, 3995-4048.

10. Combellas, C.; Delamar, M.; Kanoufi, F.; Pinson, J.; Podvorica, F.I. Spontaneous Grafting of Iron Surfaces by Reduction of Aryldiazonium Salts in Acidic or Neutral Aqueous Solution. Application to the Protection of Iron against Corrosion. Chem. Mater. 2005, 17, 3968-3975.

11. Zhu, Y.; Higginbotham, A.L.; Tour, J.M. Covalent Functionalization of Surfactant-Wrapped Graphene Nanoribbons. Chem. Mater. 2009, 21, 5284-5291.

12. Lomeda, J.R.; Doyle, C.D.; Kosynkin, D.V.; Hwang, W.-F.; Tour, J.M. Diazonium Functionalization of Surfactant-Wrapped Chemically Converted Graphene Sheets. J. Am. Chem. Soc. 2008, 130, 16201-16206.

13. Gehan, H.; Fillaud, L.; Felidj, N.; Aubard, J.; Lang, P.; Chehimi, M.M.; Mangeney, C.A. General Approach Combining Diazonium Salts and Click Chemistries for Gold Surface Functionalization by Nanoparticle Assemblies. Langmuir 2010, 26, 3975-3980.

14. Mirkhalaf, F.; Paprotny, J.; Schiffrin, D.J. Synthesis of Metal Nanoparticles Stabilized by Metal-Carbon Bonds. J. Am. Chem. Soc. 2006, 128, 7400-7401.

15. Ghosh, D.; Chen, S.W. Palladium Nanoparticles Passivated by Metal-Carbon Covalent Linkages. J. Mater. Chem. 2008, 18, 755-762.

16. Ratheesh Kumar, V.K.; Gopidas, K.R. Synthesis and Characterization of Gold-NanoparticleCored Dendrimers Stabilized by Metal-Carbon Bonds. Chem. Asian J. 2010, 5, 887-896.

17. Ratheesh Kumar, V.K.; Gopidas, K.R. Palladium Nanoparticle-Cored G1-Dendrimer Stabilized by Carbon-Pd Bonds: Synthesis, Characterization and use as Chemoselective, Room Temperature Hydrogenation Catalyst. Tetrahedron Lett. 2011, 52, 3102-3105.

18. Ratheesh Kumar, V.K.; Krishnakumar, S.; Gopidas, K.R. Synthesis, Characterization and Catalytic Applications of Palladium Nanoparticle-Cored Dendrimers Stabilized by Metal-Carbon Bonds. Eur. J. Org. Chem. 2012, 3447-3458.

19. Laurentius, L.; Stoyanov, S.R.; Gusarov, S.; Kovalenko, A.; Du, R.; Lopinski, G.P.; McDermott, M.T. Diazonium-Derived Aryl Films on Gold Nanoparticles: Evidence for a Carbon-Gold Covalent Bond. ACS Nano 2011, 5, 4219-4227. 
20. Adenier, A.; Bernard, M.C.; Chehimi, M.M.; Cabet-Deliry, E.; Desbat, B.; Fagebaume, O.; Pinson, J.; Podvorica, F. Covalent Modification of Iron Surfaces by Electrochemical Reduction of Aryldiazonium Salts. J. Am. Chem. Soc. 2001, 123, 4541-4549.

21. Nakamura, T.; Suzuki, M.; Ishihara, M.; Ohana, T.; Tanaka, A.; Koga, Y. Photochemical Modification of Diamond Films: Introduction of Perfluorooctyl Functional Groups on Their Surface. Langmuir 2004, 20, 5846-5849.

22. Harper, J.C.; Polsky, R.; Wheeler, D.R.; Brozik, S.M. Maleimide-Activated Aryl Diazonium Salts for Electrode Surface Functionalization with Biological and Redox Active Molecules. Langmuir 2008, 24, 2206-2211.

23. Corgier, B.P.; Marquette, C.A.; Blum, L.J. Diazonium-Protein Adducts for Graphite Electrode Microarrays Modification: Direct and Addressed Electrochemical Immobilization. J. Am. Chem. Soc. 2005, 127, 18328-18332.

24. Mévellec, V.; Roussel, S.; Tessier, L.; Chancolon, J.; Mayne-L’Hermite, M.; Deniau, G.; Viel, P.; Palacin, S. Grafting Polymers on Surfaces: A New Powerful and Versatile Diazonium Salt-Based One-Step Process in Aqueous Media. Chem. Mater. 2007, 19, 6323-6330.

25. Garrett, D.J.; Lehr, J.; Miskelly, G.M.; Downard, A.J. Microcontact Printing using the Spontaneous Reduction of Aryldiazonium Salts. J. Am. Chem. Soc. 2007, 129, 15456-15457.

26. Hossain, M.Z.; Walsh, M.A.; Hersam, M.C. Scanning Tunneling Microscopy, Spectroscopy, and Nanolithography of Epitaxial Graphene Chemically Modified with Aryl Moieties. J. Am. Chem. Soc. 2010, 132, 15399-15403.

27. Roglans, A.; Pla-Quintana, A.; Moreno-Manas, M. Diazonium Salts as Substrates in PalladiumCatalyzed Cross-Coupling Reactions. Chem. Rev. 2006, 106, 4622-4643.

28. Patai, S. The Chemistry of Diazonium and Diazo Groups. The Chemistry of Functional Groups; John Wiley \& Sons Inc: New York, NY, USA, 1978; Volume 2.

29. Saunders, K.H. The Aromatic Diazo-Compounds and Their Technical Applications; Edward Arnold \& Co.: London, UK, 1949.

30. Zollinger, H. Diazotization of Amines and Dediazoniation of Diazonium Ions. In The Chemistry of Amino, Nitroso, Nitro and Related Groups; Patai, S., Ed.; Wiley \& Sons: New York, NY, USA, 1996; pp. 636-637.

31. Chamoulaud, G.; Bélanger, D. Spontaneous Derivatization of a Copper Electrode with in situ Generated Diazonium Cations in Aprotic and Aqueous Media. J. Phys. Chem. C 2007, 111, 7501-7507.

32. Glaser, R.; Horan, C.J. Benzenediazonium Ion. Generality, Consistency, and Preferability of the Electron Density Based Dative Bonding Model. J. Org. Chem. 1995, 60, 7518-7528.

33. Glaser, R.; Horan, C.J.; Lewis, M.; Zollinger, H. $\sigma$-Dative and $\pi$-Backdative Phenyl Cation-Dinitrogen Interactions and Opposing Sign Reaction Constants in Dual Substituent Parameter Relations. J. Org. Chem. 1999, 64, 902-913.

34. Gokel, G.W.; Cram, D.J. Molecular Complexation of Arenediazonium and Benzoyl Cations by Crown Ethers. J. Chem. Soc. Chem. Commun. 1973, 481-482.

35. Kuokkanen, T.; Haataja, A. Effect of Solvent on the Complexation and Thermal Stability of Benzenediazonium Tetrafluoroborate in the Presence of Crown Ethers. Acta Chem. Scand. 1993, $47,872-876$. 
36. Morosin, B.; Lingafelter, E.C. The Crystal Structure of Tetramethylammonium Tetrachlorozincate and Tetrachlorocobaltate. Acta Crystallogr. 1959, 12, 611-612.

37. Doctorovich, F.; Escola, N.; Trápani, C.; Estrin, D.A.; Lebrero, M.C.G.; Turjanski, A.G. Stabilization of Aliphatic and Aromatic Diazonium Ions by Coordination: An Experimental and Theoretical Study. Organometallics 2000, 19, 3810-3817.

38. Mohamed, A.A. Advances in the Coordination Chemistry of Nitrogen Ligand Complexes of Coinage Metals. Coord. Chem. Rev. 2010, 254, 1918-1947.

39. Overton, A.T.; Mohamed, A.A. Gold Diazonium Complexes for Electrochemical Reductive Grafting. Inorg. Chem. 2012, 51, 5500-5502.

40. Gougoutas, J.Z.; Johnson, J. Structure and Solid-State Chemistry of 3-Carboxy-2Naphthalenediazonium Bromide. J. Am. Chem. Soc. 1978, 100, 5816-5820.

41. Greenberg, B.; Okaya, Y. Crystal and Molecular Structure of 2-Diazonium-4-Phenolsulfonate Monohydrate, $\mathrm{C}_{6} \mathrm{H}_{3} \mathrm{~N}_{2}{ }^{+} \cdot \mathrm{SO}_{3}{ }^{-} \cdot \mathrm{OH} . \mathrm{H}_{2} \mathrm{O}$. Acta Cryst. B 1969, 25, 2101-2108.

42. Mostad, A.; Rømming, C. The Crystal Structure of p-Benzenebisdiazonium Tetrachlorozincate. Acta Chem. Scand. 1968, 22, 1259-1266.

43. Romming, C. The Structure of Benzene Diazonium Chloride. Acta Chem. Scand. 1963, 17, 1444-1454.

44. Romming, C. The Crystal Structure of p-Benzenediazonium Sulphonate. Acta Chem. Scand. 1972, $26,523-533$.

45. Romming, C.; Tjornhom, T. The Crystal Structure of the 1:1 Complex Benzenediazonium Chloride-Acetic Acid. Acta Chem. Scand. 1968, 22, 2934-2942.

46. Filimonov, V.D.; Trusova, M.; Postnikov, P.; Krasnokutskaya, E.A.; Lee, Y.M.; Hwang, H.Y.; Kim, H.; Chi, K.-W. Unusually Stable, Versatile, and Pure Arenediazonium Tosylates: Their Preparation, Structures, and Synthetic Applicability. Org. Lett. 2008, 10, 3961-3964.

47. Pauling, L. The Nature of the Chemical Bond, 3rd ed.; Cornell University Press: Ithaca, NY, USA, 1960.

48. Gremillion, A.F.; Jonassen, H.B.; O’Connor, R.J. The Thermal Stabilities and Infrared Spectra of some Metal Salt Stabilized Diazonium Salts. J. Am. Chem. Soc. 1959, 81, 6134-6138.

49. Savitsky, A.; Siggia, S. Analysis of Primary Aromatic Amines and Nitrite by Diazotization and Pyrolysis Gas Chromatography. Anal. Chem. 1974, 46, 149-152.

50. SMART, Version 4.043; Software for the CCD Detector System; Bruker Analytical X-ray Systems: Madison, WI, USA, 1995.

51. SAINT, Version 4.035; Software for the CCD Detector System; Bruker Analytical X-ray Systems: Madison, WI, USA, 1995.

52. Blessing, R.H. SADABS. Program for absorption corrections using Siemens CCD based on the method of Robert Blessing. Acta Cryst. A 1995, 51, 33.

53. Scheldrick, G.M. SHELXS-97; Program for the Solution of Crystal Structure; University of Göttingen, Göttingen, Germany, 1997. 
54. SHELXTL 5.03; Program Library for Structure Solution and Molecular Graphics; Bruker Analytical X-ray Systems: Madison, WI, USA, 1995.

(C) 2013 by the authors; licensee MDPI, Basel, Switzerland. This article is an open access article distributed under the terms and conditions of the Creative Commons Attribution license (http://creativecommons.org/licenses/by/3.0/). 